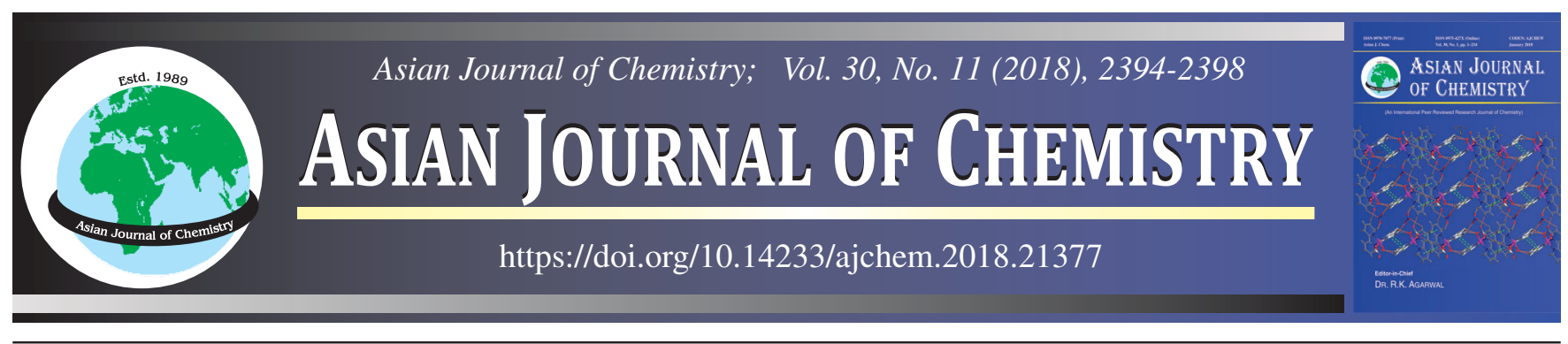

\title{
Study of Radical Scavenging Activities of a Series of Flavonoids through 3D-QSAR Analysis
}

\author{
AnANDA Sarkar ${ }^{1}$, Atish Dipankar Jana ${ }^{2, *}$ and Nabanita Giri ${ }^{3}$
}

${ }^{1}$ Department of Physics, Acharya Prafulla Chandra College, Kolkata-700 131, India

${ }^{2}$ Department of Physics, Behala College, Parnasree, Kolkata-700 060, India

${ }^{3}$ Department of Microbiology, Acharya Prafulla Chandra College, Kolkata-700 131, India

*Corresponding author: E-mail: atish@behalacollege.in; atishdipankarjana@yahoo.in

Flavonoids are efficient antioxidants having free radical scavenging property. A set of 29 flavonoids whose radical scavenging activities are known, have been chosen to understand the origin of their radical scavenging activities. 3D-QSAR models have been established through comparative molecular field analysis (CoMFA) and comparative molecular similarity indices analysis (CoMSIA) procedure which reveal that the electron withdrawing groups from pyrone ring is likely to increase the radical scavenging activities. Also hydrogen bond donor groups on pyrone moiety and its adjacent ring are preferred for better radical scavenging activitiies. |

| Keywords: Flavonoids, Radical scavenging activity, CoMFA, CoMSIA, Pyrone ring.

\section{INTRODUCTION}

Free radicals are the spontaneous outcome of metabolic processes in all living beings and are considered to be the main cause behind cell death and ageing [1]. Free radicals are very much unstable and highly reactive leading to unwanted electron transfer, proton transfer, $\mathrm{H}$-atom abstraction or addition which harm various organs and tissues of living being. Oxy radicals have been found to be responsible for diseases like rheumatoid arthritis, cancer, inflammation, coronary heart disease, diabetes, Parkinson's disease, cystic fibrosis, Alzheimer's disease and many others [2-8]. Antioxidants are mostly naturally occurring substances, abundant in fruits and vegetables. These are broadly classified into three classes depending on their action (a) as scavangers, (b) metal chelators and (c) as enzyme inhibitors $[9,10]$. Whereas scavenging type antioxidants directly removes radicals, two other types of antioxidants prevent the generation of radicals indirectly. The scavenging type antioxidants have received most attention due to their direct mode of action [11].

Flavonoids are multiple-OH containing molecules found in various natural sources like fruits, vegetables, tea, wine, etc. These molecules are present in various parts of plants like stems, bark, roots, grains and even in flowers [12-15]. Intake of these substances lead to scavenging of free radicals and thus flavonoids prevent injury to cells and tissues. Radicals oxidize antioxidant molecules and subsequently become more stable and less reactive.

Study of reactivity of antioxidant molecules through electronic structure analysis and their capacity to scavenge free radicals has drawn much attention of scientific community. Quantitative structure activity relationship (QSAR) $[16,17]$ is an efficient methodology towards unraveling the electronic level information responsible for activities of a set of molecules.

The aim of the present study is to establish a connection between molecular structure of flavonoids (flavones, flavonols and flavanones) and their activities to scavenge 1,1-diphenyl2-picrylhydrazyl (DPPH ${ }^{\bullet}$ ) free radical. In the present work, 3D-QSAR studies for a set of 29 flavonoids have been carried out to understand their antioxidant activities. Comparative molecular field analysis (CoMFA) [18] and comparative molecular similarity indices analysis (CoMSIA) [19,20] methods reveal the nature of radical scavenging activities of flavonoids and provides important insights on the $3 \mathrm{D}$ structural aspects and electronic level information for these molecules that are responsible for their excellent antioxidant activities.

This is an open access journal, and articles are distributed under the terms of the Creative Commons Attribution-NonCommercial 4.0 International (CC BY-NC 4.0) License, which allows others to copy and redistribute the material in any medium or format, remix, transform, and build upon the material, as long as appropriate credit is given and the new creations are licensed under the identical terms. 


\section{EXPERIMENTAL}

Selection of dataset: In Table-1, a set of 29 flavonoids are listed, which have proven 1,1-diphenyl-2-picrylhydrazyl $\left(\mathrm{R}^{\circ}\right)(\mathrm{DPPH})$ radical scavenging activity (RSA \%) [21]. RSA\% values of the chosen set of molecules have been converted to $\log ($ RSA \%) that varies in the range from -0.22 to 1.98 . A test set of five molecules that evenly spanned the RSA activity range was utilized to test the external predictivity of the constructed QSAR models. These molecules were subsequently removed from the original data set in the fomation of QSAR model.

Sybyl X molecular modeling package [22] was used for construction of 3D-QSAR models (CoMFA and CoMSIA). Structural energy minimization for all 29 molecules were carried out using the Tripos force field. Powell gradient algorithm with a convergence criterion of $0.001 \mathrm{kcal} \mathrm{mol}^{-1}$ was used for this optimization. Gasteiger-Hückel method was employed to compute partial atomic charges.

Molecular alignment: Molecular alignment is the most crucial step in the development of CoMFA and CoMSIA models [23]. In this study, ligand based alignment technique has been chosen where a template molecule was selected over which all the remaining molecules were aligned. In this work, molecule 14 (morin) having the most potent activity within the dataset was used as template molecule. The aligned set of molecules has been depicted in Fig. 1.

CoMFA and CoMSIA setup: The CoMFA and CoMSIA models were constructed separately for the aligned molecular data set. Descriptor fields in CoMFA and CoMSIA models were computed over a 3D cubic lattice with $1 \AA$ A grid spacing which

TABLE-1

MOLECULAR STRUCTURES OF FLAVONOID MOLECULES AND THEIR RADICAL SCAVENGING ACTIVITIES IN LOGARITHM SCALE
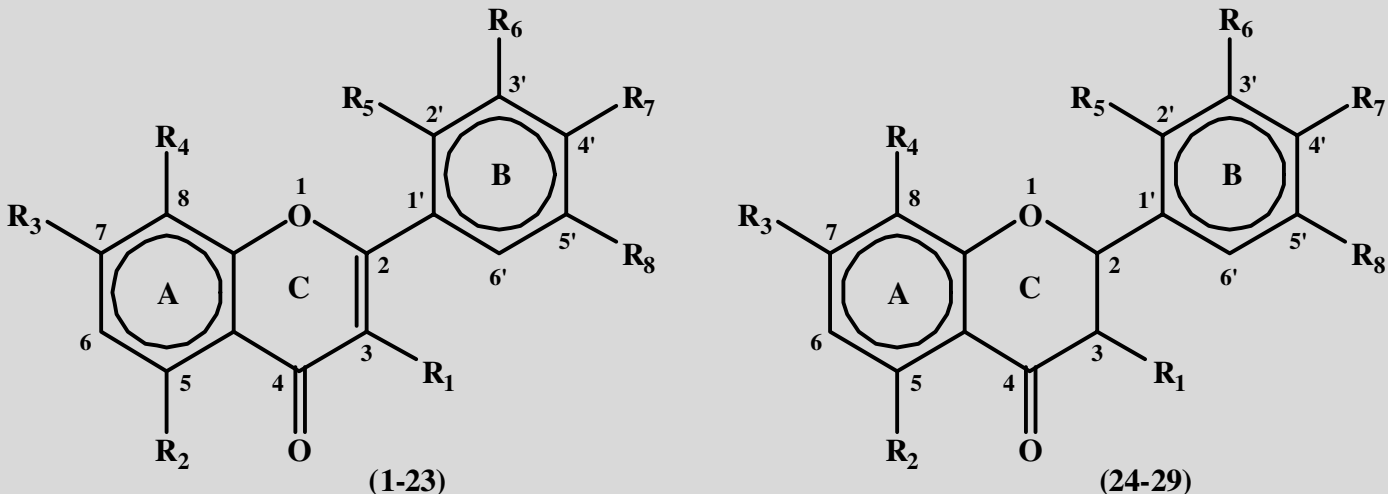

$(1-23)$

(24-29)

\begin{tabular}{|c|c|c|c|c|c|c|c|c|c|c|}
\hline No. & Name & $\mathrm{R}_{1}$ & $\mathrm{R}_{2}$ & $\mathrm{R}_{3}$ & $\mathrm{R}_{4}$ & $\mathrm{R}_{5}$ & $\mathrm{R}_{6}$ & $\mathrm{R}_{7}$ & $\mathrm{R}_{8}$ & Activity \\
\hline 1 & Kaempferol & $\mathrm{OH}$ & $\mathrm{OH}$ & $\mathrm{OH}$ & $\mathrm{H}$ & $\mathrm{H}$ & $\mathrm{H}$ & $\mathrm{OH}$ & $\mathrm{H}$ & 1.971 \\
\hline 2 & Galangin & $\mathrm{OH}$ & $\mathrm{OH}$ & $\mathrm{OH}$ & $\mathrm{H}$ & $\mathrm{H}$ & $\mathrm{H}$ & $\mathrm{H}$ & $\mathrm{H}$ & 1.963 \\
\hline 3 & Quercetin & $\mathrm{OH}$ & $\mathrm{OH}$ & $\mathrm{OH}$ & $\mathrm{H}$ & $\mathrm{H}$ & $\mathrm{OH}$ & $\mathrm{OH}$ & $\mathrm{H}$ & 1.953 \\
\hline 4 & Kaempferol 3,7-dirh & Orh & $\mathrm{OH}$ & Orh & $\mathrm{H}$ & $\mathrm{H}$ & $\mathrm{H}$ & $\mathrm{OH}$ & $\mathrm{H}$ & 1.845 \\
\hline 5 & Robinetin & $\mathrm{OH}$ & $\mathrm{H}$ & $\mathrm{OH}$ & $\mathrm{H}$ & $\mathrm{H}$ & $\mathrm{OH}$ & $\mathrm{OH}$ & $\mathrm{OH}$ & 1.915 \\
\hline 6 & Fisetin & $\mathrm{OH}$ & $\mathrm{H}$ & $\mathrm{OH}$ & $\mathrm{H}$ & $\mathrm{H}$ & $\mathrm{OH}$ & $\mathrm{OH}$ & $\mathrm{H}$ & 1.898 \\
\hline 7 & 3-hydroxyflavone & $\mathrm{OH}$ & $\mathrm{H}$ & $\mathrm{H}$ & $\mathrm{H}$ & $\mathrm{H}$ & $\mathrm{H}$ & $\mathrm{H}$ & $\mathrm{H}$ & 1.820 \\
\hline 8 & Laricytrin & $\mathrm{OH}$ & $\mathrm{OH}$ & $\mathrm{OH}$ & $\mathrm{H}$ & $\mathrm{H}$ & $\mathrm{OH}$ & $\mathrm{OH}$ & $\mathrm{OMe}$ & 1.927 \\
\hline 9 & Laricytrin $3^{\prime}-\mathrm{O}$-glucoside & $\mathrm{OH}$ & $\mathrm{OH}$ & $\mathrm{OH}$ & $\mathrm{H}$ & $\mathrm{H}$ & $\mathrm{Ogl}$ & $\mathrm{OH}$ & $\mathrm{OMe}$ & 1.923 \\
\hline 10 & Myricetin & $\mathrm{OH}$ & $\mathrm{OH}$ & $\mathrm{OH}$ & $\mathrm{H}$ & $\mathrm{H}$ & $\mathrm{OH}$ & $\mathrm{OH}$ & $\mathrm{OH}$ & 1.862 \\
\hline 11 & $3,5,7,3^{\prime}, 4^{\prime}, 5^{\prime}$ hexameth. Flavones & $\mathrm{OMe}$ & $\mathrm{OMe}$ & $\mathrm{OMe}$ & $\mathrm{H}$ & $\mathrm{H}$ & $\mathrm{OMe}$ & $\mathrm{OMe}$ & $\mathrm{OMe}$ & 1.100 \\
\hline 12 & Quercetin 3-O-glu-7-O-rhamnose & Ogl & $\mathrm{OH}$ & Orh & $\mathrm{H}$ & $\mathrm{H}$ & $\mathrm{OH}$ & $\mathrm{OH}$ & $\mathrm{H}$ & 1.939 \\
\hline 13 & Rutin & Oru & $\mathrm{OH}$ & $\mathrm{OH}$ & $\mathrm{H}$ & $\mathrm{H}$ & $\mathrm{OH}$ & $\mathrm{OH}$ & $\mathrm{H}$ & 1.959 \\
\hline 14 & Morin & $\mathrm{OH}$ & $\mathrm{OH}$ & $\mathrm{OH}$ & $\mathrm{H}$ & $\mathrm{OH}$ & $\mathrm{H}$ & $\mathrm{OH}$ & $\mathrm{H}$ & 1.985 \\
\hline 15 & Flavone & $\mathrm{H}$ & $\mathrm{H}$ & $\mathrm{H}$ & $\mathrm{H}$ & $\mathrm{H}$ & $\mathrm{H}$ & $\mathrm{H}$ & $\mathrm{H}$ & 0.176 \\
\hline 16 & 5-hydroxyflavone & $\mathrm{H}$ & $\mathrm{OH}$ & $\mathrm{H}$ & $\mathrm{H}$ & $\mathrm{H}$ & $\mathrm{H}$ & $\mathrm{H}$ & $\mathrm{H}$ & -0.222 \\
\hline 17 & 7-hydroxyflavone & $\mathrm{H}$ & $\mathrm{H}$ & $\mathrm{OH}$ & $\mathrm{H}$ & $\mathrm{H}$ & $\mathrm{H}$ & $\mathrm{H}$ & $\mathrm{H}$ & 0.447 \\
\hline 18 & Crysin & $\mathrm{H}$ & $\mathrm{OH}$ & $\mathrm{OH}$ & $\mathrm{H}$ & $\mathrm{H}$ & $\mathrm{H}$ & $\mathrm{H}$ & $\mathrm{H}$ & 0.041 \\
\hline 19 & 8-methoxyflavone & $\mathrm{H}$ & $\mathrm{H}$ & $\mathrm{OMe}$ & $\mathrm{H}$ & $\mathrm{H}$ & $\mathrm{H}$ & $\mathrm{H}$ & $\mathrm{H}$ & -0.155 \\
\hline 20 & Apigenin & $\mathrm{H}$ & $\mathrm{OH}$ & $\mathrm{OH}$ & $\mathrm{H}$ & $\mathrm{H}$ & $\mathrm{H}$ & $\mathrm{OH}$ & $\mathrm{H}$ & -0.155 \\
\hline 21 & Vitexin & $\mathrm{H}$ & $\mathrm{OH}$ & $\mathrm{OH}$ & Gl & $\mathrm{H}$ & $\mathrm{H}$ & $\mathrm{OH}$ & $\mathrm{H}$ & 1.322 \\
\hline 22 & Apigenin 7-O-glucoside & $\mathrm{H}$ & $\mathrm{OH}$ & Ogl & $\mathrm{H}$ & $\mathrm{H}$ & $\mathrm{H}$ & $\mathrm{OH}$ & $\mathrm{H}$ & 1.542 \\
\hline 23 & Luteolin 7-O-glucoside & $\mathrm{H}$ & $\mathrm{OH}$ & Ogl & $\mathrm{H}$ & $\mathrm{H}$ & $\mathrm{OH}$ & $\mathrm{OH}$ & $\mathrm{H}$ & 1.943 \\
\hline 24 & Flavanone & $\mathrm{H}$ & $\mathrm{H}$ & $\mathrm{H}$ & $\mathrm{H}$ & $\mathrm{H}$ & $\mathrm{H}$ & $\mathrm{H}$ & $\mathrm{H}$ & 0.415 \\
\hline 25 & Naringenin & $\mathrm{H}$ & $\mathrm{OH}$ & $\mathrm{OH}$ & $\mathrm{H}$ & $\mathrm{H}$ & $\mathrm{H}$ & $\mathrm{OH}$ & $\mathrm{H}$ & 0.799 \\
\hline 26 & Naringin & $\mathrm{H}$ & $\mathrm{OH}$ & One & $\mathrm{H}$ & $\mathrm{H}$ & $\mathrm{H}$ & $\mathrm{OH}$ & $\mathrm{H}$ & 0.672 \\
\hline 27 & Hesperetin & $\mathrm{H}$ & $\mathrm{OH}$ & $\mathrm{OH}$ & $\mathrm{H}$ & $\mathrm{H}$ & $\mathrm{OH}$ & $\mathrm{OMe}$ & $\mathrm{H}$ & 1.477 \\
\hline 28 & Fustin & $\mathrm{OH}$ & $\mathrm{H}$ & $\mathrm{OH}$ & $\mathrm{H}$ & $\mathrm{H}$ & $\mathrm{OH}$ & $\mathrm{OH}$ & $\mathrm{H}$ & 1.963 \\
\hline 29 & Taxifolin (dih) & $\mathrm{OH}$ & $\mathrm{OH}$ & $\mathrm{OH}$ & $\mathrm{H}$ & $\mathrm{H}$ & $\mathrm{OH}$ & $\mathrm{OH}$ & $\mathrm{H}$ & 1.977 \\
\hline
\end{tabular}

$\mathrm{Ogl} \rightarrow$ O-glucoside; Orh $\rightarrow$ O-rhamnoside; One $\rightarrow$ O-neohesp; OMe $\rightarrow$ Methoxy; Oru $\rightarrow$ O-rutinoside; dirh $\rightarrow$ dirhamnoside; dih $\rightarrow$ dihydroquercetin 


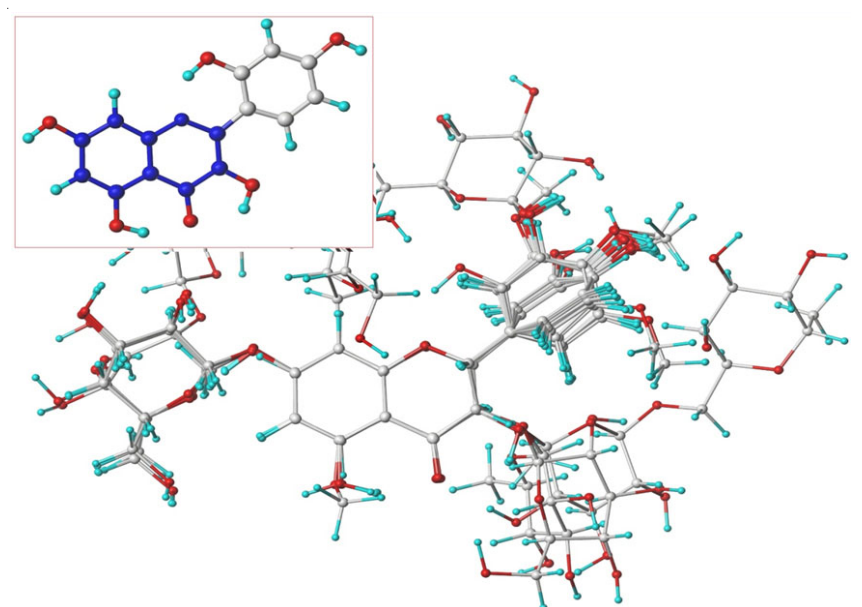

Fig. 1. Molecules have been aligned over the template molecule 14 which is shown in the inset. The common moiety is the pyrone moiety and the adjacent phenyl group marked in magenta

extended $4 \AA$ A beyond the aligned set of molecules in all directions. The van dar Waals potentials and coulombic terms were calculated by using Tripos force field. In CoMFA procedure, a $s p^{3}$ hybridized carbon atom with a charge of +1 was utilized as the probe atom to calculate steric and electrostatic fields, in which their energy values were truncated at $30 \mathrm{kcal} / \mathrm{mol}$. In CoMSIA procedure also the same lattice box was used. Steric, electrostatic, hydrophobic, hydrogen bond donor and hydrogen bond acceptor fields were computed using a probe atom of radius $1.0 \AA$ and charge +1.0 . The attenuation factor was set to its default value of 0.3 .

Derivation and validation of model: Partial least squares (PLS), an extension of multiple regression analysis were used to find the linear relationship between CoMFA fields and log (RSA \%) values. Similarly, another linear relationship was established between CoMSIA and log (RSA \%) values. The cross-validation analysis was performed using the leave-oneout (LOO) method, in which one molecule was removed from the data set and its activity was predicted using the model derived from the rest of data set [24]. Partial least squares (PLS) was combined with cross-validation option to determine the optimum

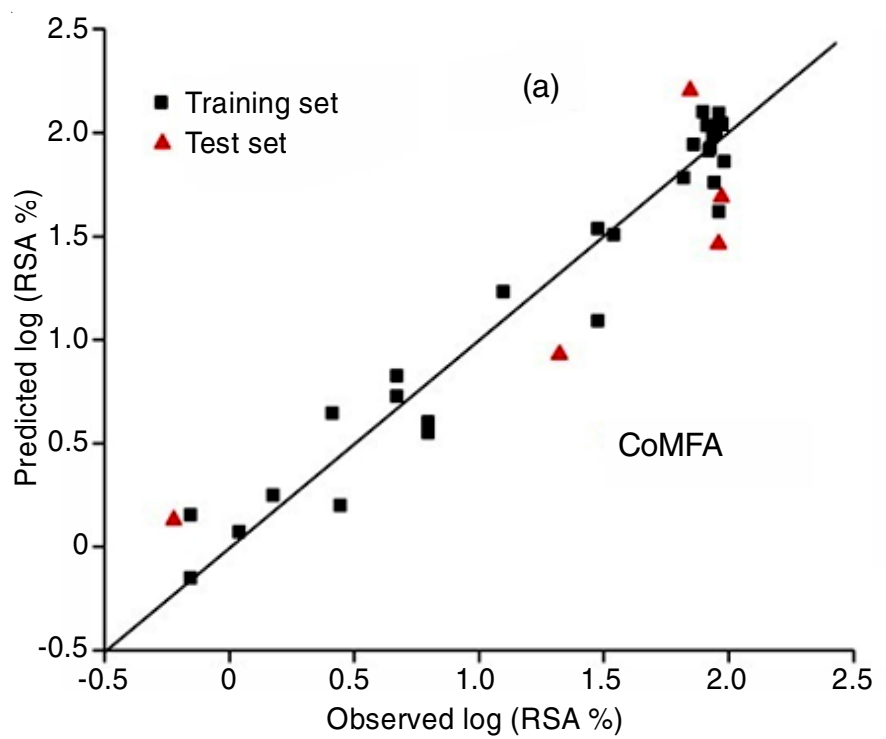

number of components (ONC), which were then used in deriving the final CoMFA and CoMSIA model without cross-validation. The ONC is the number of components that resulted in highest cross-validated correlated correlation coefficient $\left(\mathrm{r}_{\mathrm{cv}}{ }^{2}\right.$ or $\left.\mathrm{q}^{2}\right)$. Column filtering was used at the default value of $2.0 \mathrm{kcal} / \mathrm{mol}$ in the cross-validation part. The final models were developed by using non-cross-validated analysis with ONC that yielded the highest correlation coefficient $r^{2}$. The predictive abilities were determined from a test set of seven molecules that were not included in the training set. These molecules were aligned to template and their log (RSA \%) values were then predicted. The predictive correlation coefficient $\left(\mathrm{r}_{\text {pred }}^{2}\right)$, based on the molecules of the test set is calculated using eqn. 1 .

$$
\mathrm{r}_{\text {pred }}^{2}=1-\frac{\left.\sum\left(\mathrm{Y}_{\text {obs (test) }}-\mathrm{Y}_{\text {pred(test }}\right)\right)^{2}}{\sum\left(\mathrm{Y}_{\text {obs (test) }}-\overline{\mathrm{Y}}_{\text {training }}\right)^{2}}
$$

where $\mathrm{Y}_{\text {pred(test) }}$ and $\mathrm{Y}_{\mathrm{obs}(\mathrm{test})}$ indicate, respectively, the predicted and observed activity values of test set molecules and $\bar{Y}_{\text {training }}$ indicates the mean activity value of the training set molecules. The value of $r^{2}$ pred for an acceptable model should be greater than 0.5 [25].

\section{RESULTS AND DISCUSSION}

The CoMFA model using both steric and electrostatic fields gave a cross-validated correlation coefficient $\left(q^{2}\right)$ of 0.666 with an optimized number of components of five. A high non-crossvalidated correlation coefficient $\left(\mathrm{r}^{2}\right)$ of 0.952 with a low standard error estimate (SEE) of 0.197 and a good F value of 70.987 was obtained. The contributions of steric and electrostatic fields were 0.650 and 0.350 , respectively. The predictive correlation coefficient $\left(\mathrm{r}_{\text {pred }}^{2}\right)$ for the accepted model is 0.791 . The graph of actual activity versus predicted log (RSA \%) of training set and test set has been illustrated in Fig. 2a.

In CoMSIA model (Fig 2b), five CoMSIA descriptors namely electrostatic field, steric field, hydrophobic field, hydrogen bond donor field, hydrogen bond acceptor field in different combinations always give different model significance and predictivity. Among 31 various possible combinations of descri-

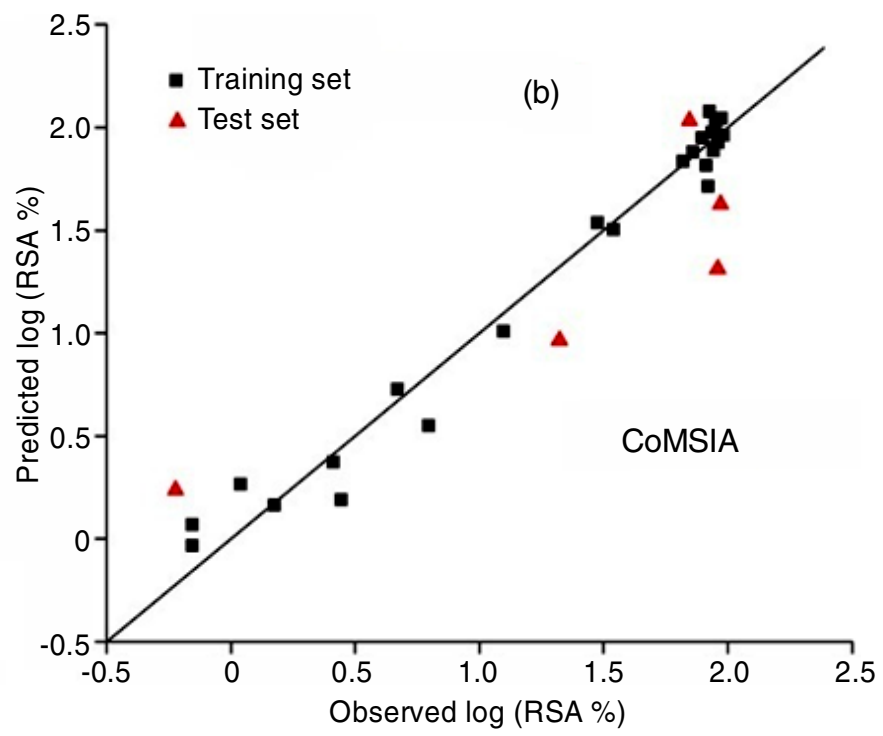

Fig. 2. Graph of actual versus predicted log (RSA \%) of the training set and the test set using (a) CoMFA model and (b) CoMSIA model 
ptors, one with hydrogen bond donor and elesctrostatic fields were found to be the best model yielding a $\mathrm{q}^{2}$ value of 0.858 , a high non-cross-validated $r^{2}$ of 0.975 with a low SEE value of 0.146 and $\mathrm{F}$ value of 110.949 . Contributions of hydrogen bond donor and electrostatic fields are 0.643 and 0.357 , respectively. The graph of actual activity versus predicted log (RSA \%) of the training set and test set has been illustrated in Fig. $2 \mathrm{~b}$. The CoMSIA model had a predictive correlation coefficient $r_{\text {pred }}^{2}=0.739$. The external validation results for both the models show that each one has high predictive power and is reliable for predicting the activities of new molecules.

Interpretation of 3D contour maps: The CoMFA steric and electrostatic contour maps have been depicted in Fig. $3 \mathrm{a}$ and Fig. 3b, respectively. These maps specify the regions in $3 \mathrm{D}$ space around the molecules where changes in the steric and electrostatic fields would increase or decrease the activity. The steric field is represented by green and yellow contours, in which green contours indicate regions where bulky groups are favourable, while the yellow contours represent regions where bulky groups would decrease the activity and small substituents are preferred. Fig. 3a shows that the prominent yellow contours are located around the substituent $R_{1}, R_{2}, R_{3}$ and $R_{6}$. This means, non-bulky substituent is preferred at these positions for better antioxidant/radical scavenging activity.

The CoMFA electrostatic contour maps (Fig. 3b) show blue contours very close to substituents $R_{2}, R_{3}$ and $R_{8}$. On the other hand, red contours are located around the substituents $R_{1}$ and $R_{5}$. The blue contours indicate electropositive groups are preferred at $R_{2}, R_{3}$ and $R_{8}$, which is expected to increase the RSA activity whereas red contours around $R_{1}$ and $R_{5}$ indicate electronegative groups at these positions are likely to increase the RSA activity.

In CoMSIA electrostatic map (Fig. 3c), blue contours are concentrated over the pyrone ring indicating the electropositive substituent on it will increase the activity. The red contour is located near $\mathrm{R}_{1}$ indicating a negative charge concentration at this position will increase the activity. The CoMFA and CoMSIA electrostatic contour maps thus correlate with each other and

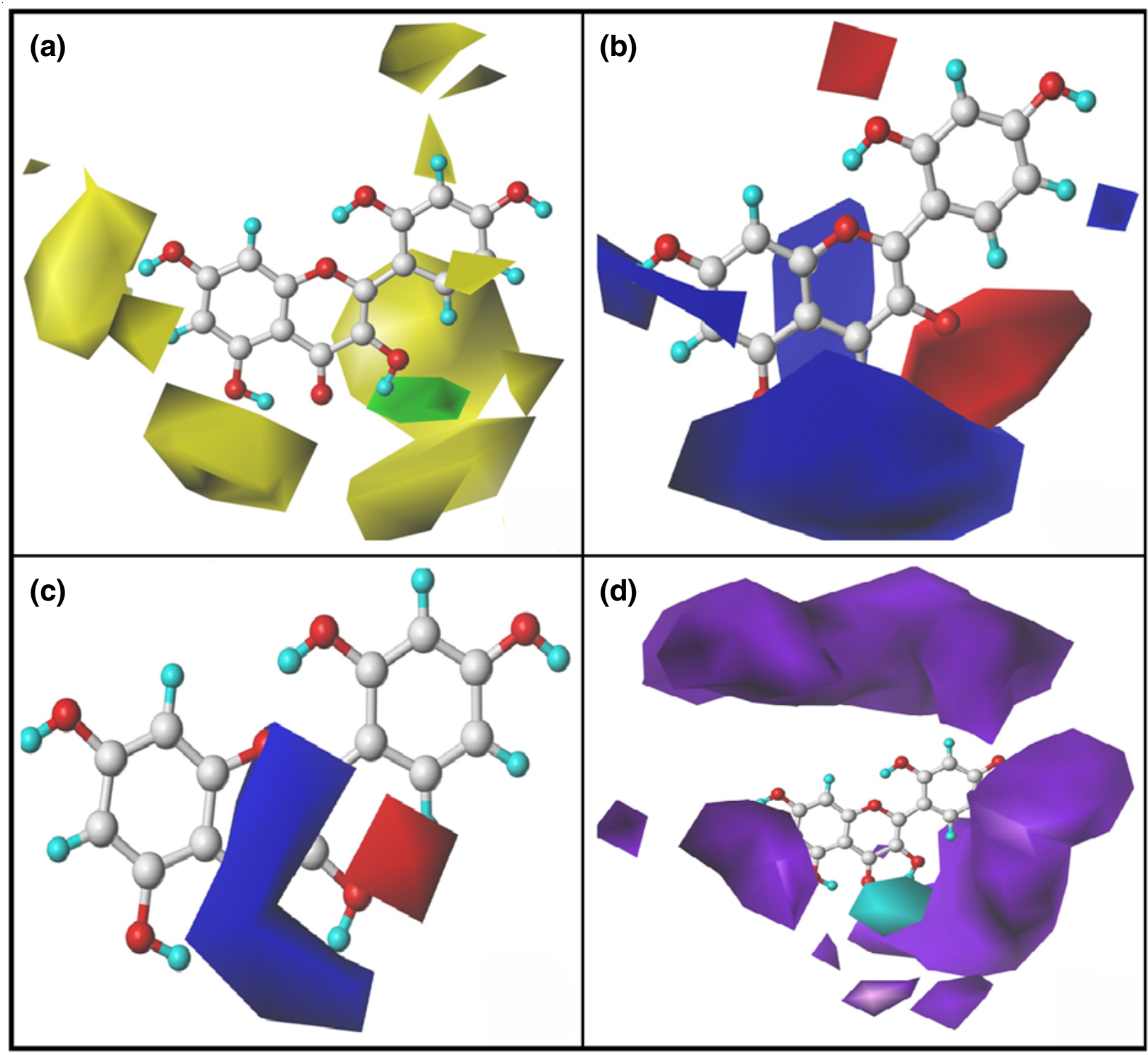

Fig. 3. (a) CoMFA contour maps for steric field, (b) CoMFA contour maps for electrostatic field, (c) CoMSIA contour maps for electrostatic field and (d) CoMSIA contour maps for hydrogen bond donor field, with highly active molecule 14, respectivel 
any electron withdrawing group from the pyrone ring at $R_{1}$ is likely to increase the RSA activity of the flavonoids.

In CoMSIA hydrogen bond donor field (Fig. 3d), one can observe very prominent purple contours near $\mathrm{R}_{1}, \mathrm{R}_{2}, \mathrm{R}_{3}, \mathrm{R}_{7}$ and $\mathrm{R}_{8}$. This indicates that hydrogen bond donor groups such as $-\mathrm{OH}$ or $-\mathrm{NH}_{2}$ at these positions would increase the activity which is in accordance with the very high hydrogen bond donor contribution (64.3\%) in the QSAR model established through CoMSIA methodology. This observation correlates very well with the experimental activity data of chosen set of molecules. Molecule 14 (morin) which is most active has -OH donor group at $\mathrm{R}_{1}, \mathrm{R}_{2}, \mathrm{R}_{3}, \mathrm{R}_{5}$ and $\mathrm{R}_{7}$ positions and molecule 1 (kempferol) the second highest active molecule has $-\mathrm{OH}$ donor groups at $\mathrm{R}_{1}, \mathrm{R}_{2}, \mathrm{R}_{3}$ and $\mathrm{R}_{7}$ positions.

\section{Conclusion}

3D-QSAR models employing CoMFA and CoMSIA procedures have been established for a set a 29 flavonoids. Molecules $\mathbf{1}$ and $\mathbf{1 4}$ having the maximum number of hydrogen bond donor sites show higher activities which is consistent with the findings from the CoMSIA procedure. It can be stated generally that better hydrogen bond donor groups at positions $\mathrm{R}_{1}, \mathrm{R}_{2}, \mathrm{R}_{3}, \mathrm{R}_{5}$ and $R_{7}$ is preferred for better radical scavenging activity of flavonoids. Also both CoMFA and CoMSIA procedure predicted that electron withdrawing groups at position $\mathrm{R}_{1}$ is suitable for higher radical scavenging activity. The knowledge gained through 3D-QSAR analysis of the chosen set of flavonoids will act as a guiding principle in the pursuit of better antioxidants.

\section{CONFLICT OF INTEREST}

The authors declare that there is no conflict of interests regarding the publication of this article.

\section{REFERENCES}

1. M.G. Simic, D.S. Bergtold and L.R. Karam, Mutat. Res., 214, 3 (1989); https://doi.org/10.1016/0027-5107(89)90192-9.

2. E.J. Middleton, C. Kandaswami and T.C. Theoharides, Pharmacol. Rev., 52, 673 (2000).

3. G. Block, Nutr. Rev., 50, 207 (1992); https://doi.org/10.1111/j.1753-4887.1992.tb01329.x.

4. J.E. Middleton, Adv. Exp. Med. Biol., 439, 175 (1998); https://doi.org/10.1007/978-1-4615-5335-9_13.
5. M. Gabor, Prog. Clin. Biol. Res., 213, 471 (1986).

6. M. Valko, M. Izakovic, M. Mazur, C.J. Rhodes and J. Telser, Mol. Cell. Biochem., 266, 37 (2004); https://doi.org/10.1023/B:MCBI.0000049134.69131.89.

7. P.A. Ward, J.S. Warren and K.J. Johnson, Free Radic. Biol. Med., 5, 403 (1988); https://doi.org/10.1016/0891-5849(88)90114-1.

8. K. Sugamura and J.F. Keaney Jr., Free Radic. Biol. Med., 51, 978 (2011); https://doi.org/10.1016/j.freeradbiomed.2011.05.004.

9. B. Halliwell, R. Aeschbach, J. Loliger and O.I. Aruoma, Food Chem. Toxicol., 33, 601 (1995); https://doi.org/10.1016/0278-6915(95)00024-V.

10. N. Cotelle, J.L. Bernier, J.P. Catteau, J. Pommery, J.C. Wallet and E.M. Gaydou, Free Radic. Biol. Med., 20, 35 (1996); https://doi.org/10.1016/0891-5849(95)02014-4.

11. H.Y. Zhang, Curr. Computeraided Drug Des., 1, 257 (2005); https://doi.org/10.2174/1573409054367691.

12. G. Di Carlo, N. Mascolo, A.A. Izzo and F. Capasso, Life Sci., 65, 337 (1999); https://doi.org/10.1016/S0024-3205(99)00120-4.

13. P.C.H. Hollman and I.C.W. Arts, J. Sci. Food Agric., 80, 1081 (2000); https://doi.org/10.1002/(SICI)1097-0010(20000515)80:7<1081::AIDJSFA566 $>3.0 . \mathrm{CO} ; 2-\mathrm{G}$.

14. S.A. Aherne and N.M. O'Brien, Nutrition, 18, 75 (2002); https://doi.org/10.1016/S0899-9007(01)00695-5.

15. P.G. Pietta, J. Nat. Prod., 63, 1035 (2000); https://doi.org/10.1021/np9904509.

16. X. Du, C. Guo, E. Hansell, P.S. Doyle, C.R. Caffrey, T.P. Holler, J.H. McKerrow and F.E. Cohen, J. Med. Chem., 45, 2695 (2002); https://doi.org/10.1021/jm010459j.

17. J. Verma, V.M. Khedkar and E.C. Coutinho, Curr. Top. Med. Chem. 10, 95 (2010); https://doi.org/10.2174/156802610790232260.

18. R.D. Cramer, D.E. Patterson and J.D. Bunce, J. Am. Chem. Soc., 110, 5959 (1988); https://doi.org/10.1021/ja00226a005.

19. H. Kubinyi, G. Folkers and Y.C. Martin, 3D QSAR in Drug Design, Kluwer, Dordrecht (1988).

20. G. Klebe, U. Abraham and T. Mietzner, J. Med. Chem., 37, 4130 (1994); https://doi.org/10.1021/jm00050a010.

21. S. Burda and W. Oleszek, J. Agric. Food Chem., 49, 2774 (2001); https://doi.org/10.1021/jf001413m.

22. SYBYL-X 2.0, Tripos Inc, St. Louis.

23. M.D.M. AbdulHameed, A. Hamza, J. Liu and C.-G. Zhan, J. Chem. Inf. Model., 48, 1760 (2008); https://doi.org/10.1021/ci800147v.

24. D.M. Hawkins, S.C. Basak and D. Mills, J. Chem. Inf. Comput. Sci., 43, 579 (2003); https://doi.org/10.1021/ci025626i.

25. P.P. Roy and K. Roy, QSAR Comb. Sci., 27, 302 (2008); https://doi.org/10.1002/qsar.200710043. 